\title{
Analisis pengaruh kredit perbankan, pembiayaan bank syariah dan investasi terhadap pertumbuhan ekonomi di Indonesia periode sebelum pandemi Covid-19 (2015-2019) dan periode pandemi Covid-19 tahun 2020
}

\author{
Deni Andrean, Imam Mukhlis* \\ Universitas Negeri Malang, Jl. Semarang No. 5 Malang, Jawa Timur, Indonesia \\ *Penulis korespondensi, Surel: imam.mukhlis.fe@um.ac.id
}

Paper received: 25-8-2021; revised: 8-9-2021; accepted: 15-9-2021

\begin{abstract}
This study aims to identify the effects of conventional banking credit, Islamic banking financing, PMA and PMDN investment on Indonesia's economic growth in the before (2015-2019) and after (20192020) Covid-19. This study used quantitative method with VAR/VECM analysis. In this study, the time series data were analyzed using eviews 10, while the comparison between before (2019) and after (2020) Covid-19 was carried out using paired samples t-test. The data were collected from various sources, including Financial Services Authority and central Bureau of Statistics. The findings show that the total investment carries significant negative effects on Indonesia's economic growth, while conventional banking credit carries no effect on Indonesia economic growth. The Islamic banking financing brings positive significant effects in long-term toward Indonesia economic growth.
\end{abstract}

Keywords: conventional bank credit; Islamic banking financing; PMA and PMDN investment; economy growth

\begin{abstract}
Abstrak
Penelitian ini bertujuan untuk mengetahui pengaruh antara kredit perbankan konvensional, pembiayaan perbankan syariah dan investasi PMA dan PMDN terhadap pertumbuhan ekonomi di Indonesia pada periode sebelum covid -19 tahun 2015 sampai 2019 dan periode covid-19 tahun 2019-2020. Penelitian ini menerapkan metode penelitian kuantitatif menggunakan analisis VAR/VECM dengan menggunakan data time series dan diolah menggunakan eviews 10, dan perbandingan perbedaan antara seluruh variabel dari tahun sebelum pandemi (2019) dan setelah adanya pandemic (2020) menggunakan pengujian Uji Beda Paired Samples t-test, data ini dikumpulkan dari berbagai sumber utama termasuk Otoritas Jasa Keuangan (OJK) dan Badan Pusat Statistik (BPS). Temuan ini menunjukkan bahwa total investasi berpengaruh negatif signifikan terhadap pertumbuhan ekonomi di Indonesia, kredit perbankan konvensional tidak berpengaruh terhadap pertumbuhan ekonomi di Indonesia. Sedangkan pada variabel pembiayaan perbankan syariah menunjukkan bahwa pembiayaan perbankan syariah berpengaruh positif signifikan dalam jangka panjang terhadap pertumbuhan ekonomi di Indonesia
\end{abstract}

Kata kunci: kredit bank konvensional; pembiayaan bank Syariah; investasi PMA dan PMDN; pertumbuhan ekonomi

\section{Pendahuluan}

Pertumbuhan ekonomi adalah salah satu indikator penting pertumbuhan ekonomi dalam suatu negara yaitu sebagai alat analisis pembangunan ekonomi yang dapat dilihat dari perbandingan PDB tahun tertentu dan tahun sebelumnya. Suatu negara dapat dianggap sejahtera salah satunya dapat dilihat melalui angka pertumbuhan ekonomi negara tersebut. Pada umumnya jika pertumbuhan ekonomi bergerak pada arah yang positif, maka dapat dikatakan negara tersebut sejahtera, dan begitu juga sebaliknya, meskipun faktor angka inflasi, 
situasi politik, pendidikan, kesehatan dll juga mempengaruhi ( Indriawati, 2016 ). Pembangunan ekonomi pada hakikatnya bertujuan untuk meningkatkan kesejahteraan masyarakat, dalam rangka meningkatkan kesejahteraan masyarakat maka diperlukan pertumbuhan ekonomi yang meningkat. Syarat yang diperlukan bagi proses pembangunan ekonomi yang berkelanjutan adalah dengan tingginya pertumbuhan ekonomi. Pertumbuhan ekonomi digunakan untuk menggambarkan suatu perekonomian yang mengalami perkembangan ekonomi dan mencapai tingkat kemakmuran yang lebih tinggi serta dampak suatu kebijakan pembangunan yang dilaksanakan, khususnya dalam bidang ekonomi. Pengeluaran pemerintah yang terlalu banyak akan menghambat pertumbuhan ekonomi.

Dalam penelitian lain yang dilakukan oleh Salahuddin El Ayyubi1, Lukytawati Anggraeni, Almira Dyah Mahiswar (2018) pada penelitian pembiayaan bank syariah terhadap pertumbuhan ekonomi Hasil penelitian diperoleh adalah adanya bidirectional causality antara pembiayaan syariah dan GDP. Pada hasil estimasi VECM menunjukkan adanya pengaruh signifikan antara perbankan syariah dan pertumbuhan ekonomi. Pada hasil IRF respon pertumbuhan ekonomi mengalami respon yang berbeda terhadap guncangan pembiayaan syariah dan Dana Pihak Ketiga (DPK). Berdasarkan hasil FEVD terlihat bahwa pembiayaan pada perbankan syariah memiliki kontribusi paling besar dalam mempengaruhi pertumbuhan ekonomi namun tidak pada DPK. Oleh karena itu, perbankan syariah harus lebih efisien dalam melakukan penyaluran DPK pada pembiayaan.

Pertumbuhan ekonomi, teori Ekonomi Klasik: (a) Teori Harrad-Domar, teori ini dikembangkan hampir diwaktu yang sama oleh Roy F, Harrad (1948) di Inggris dan Evsey D, Domar (1957) di Amerika Serikat, menurut mereka pertumbuhan ekonomi jangka panjang akan tercipta jika memenuhi persyaratan sebagai berikut: $\mathrm{G}=\mathrm{K}=\mathrm{N}$, dimana: $\mathrm{G}=$ growth, $\mathrm{K}=$ capital, $\mathrm{N}=$ tingkat pertumbuhan angkatan kerja, agar terdapat keseimbangan mana antara tabungan (S) dan Investasi (I) harus terdapat kaitan yang menyeimbangkan, padahal peran $\mathrm{K}$ untuk menghasilkan tambahan output produksi ditentukan oleh $\mathrm{v}$ (capital output ratio $=$ Rasio modal-output), (b) Teori Pertumbuhan NEOKLASIK, teori ini dikembangakn oleh Robert M, Solow ( 1970 ) dari Amerika Serikat dan TG,W Swan ( 1956) dari Australia, Model solow-Swan menggunakan unsur pertumbuhan penduduk, akumulasi kapital, kemajuan teknologi dan besarnya output yang saling berinteraksi,

Kredit Perbankan Konvensional dalam artian luas kredit diartikan sebagai kepercayaan, Begitu pun dalam bahasa latin "creder" artinya percaya, Maksud dari percaya bagi si pemberi kredit adalah bahwa ia percaya kepada si penerima kredit yang disalurkanya pasti akan dikembalikan sesuai waktu yang telah ditentukan ebelumnya, Atau sesuai perjanjian, Dan bagi penerima kredit atau peminjam mempunyai kewajiban untuk membayar sesuai jangka waktu,

Pembiayaan Perbankan Syariah adalah penyediaan uang atau tagihan yang dipersamakan dengan itu berdasarkan persetujuan atau kesepakatan antara bank dengan pihak yang dibiayai untuk mengembalikan uang atau tagihan tersebut setelah jangka waktu tertentu

Investasi PMA dan PMDN, menurut Undang - Undang Nomor 1 tahun 1967 pasal 1 tentang Penanaman Modal Asing yang berbunyi "Pengertian penanaman modal asing di dalam Undangundang ini hanyalah meliputi penanaman modal asing secara langsung yang dilakukan menurut atau berdasarkan ketentuan-ketentuan Undang-undang ini dan yang digunakan untuk menjalankan perusahaan di Indonesia, dalam arti bahwa pemilik modal secara langsung menanggung risiko dari penanaman modal tersebut" Investasi Penanaman Modal Asing (PMA) 
adalah alat pembayaran luar negeri yang tidak merupakan bagian dari kekayaan devisa Indonesia. Yang dengan persetujuan pemerintah digunakan untuk pembiayaan perusahaan di Indonesia. Investasi PMA juga sebagai alat - alat perusahaan, termasuk penemuan baru milik orang asing dan bahan - bahan, yang dimasukan dari luar negeri ke Indonesia, selama alat alat tersebut tidak dibiayai dari kekayaan devisa Indonesia. Sedangkan pengertian Penanaman Modal Dalam Negeri (PMDN) dijelaskan dalam Undang = Undang Nomor 6 tahun 1968 "Pasal 1 Yang dimaksud dalam Undang-undang ini dengan "Modal Dalam Negeri ialah:Bagian daripada kekayaan masyarakat Indonesia, termasuk hak-hak dan benda-benda, baik yang dimiliki oleh Negara maupun swasta nasional atau swasta asing yang berdomisili di Indonesia, yang disisihkan/disediakan guna menjalankan sesuatu usaha sepanjang modal tersebut tidak diatur oleh ketentuan-ketentuan pasal 2 Undang-undang No. 1 tahun 1967 tentang Penanaman Modal Asing"

\section{Metode}

Teknik analisis yang digunakan dalam penelitian ini adalah analisis data kuantitatif dengan Teknik analisis sebagai berikut:

\subsection{Teknik Analisis VAR/VECM}

Tahapan dari Teknik analisis tersebut adalah uji Stasionieritas, uji panjang lag, uji stabilitias, uji kointegrasi, uji kausalitas Grenger, uji VAR/VECM, uji Variant Decomposition, uji IRF 


\section{Hasil dan Pembahasan}

\subsection{Uji Stasionieritas}

Tabel 1. Hasil Uji Akar Unit

\begin{tabular}{|c|c|c|c|c|c|}
\hline Variabel & Tingkat & $\begin{array}{c}\mathrm{t}- \\
\text { statistic }\end{array}$ & $\begin{array}{c}\text { Critical } \\
\text { Value }\end{array}$ & Prob. & Keterangan \\
\hline \multirow{3}{*}{ Kredit } & Level & $\begin{array}{l}- \\
0.15125 \\
1\end{array}$ & -2.913549 & 0.9382 & Non Stasioner \\
\hline & $\begin{array}{l}\mathbf{1}^{\text {st }} \\
\text { Difference }\end{array}$ & $\begin{array}{l}- \\
4.55997 \\
8\end{array}$ & -2.913549 & 0.0005 & Stasioner \\
\hline & $\begin{array}{l}2^{n d} \\
\text { Difference }\end{array}$ & $\begin{array}{l}- \\
6.74635 \\
2\end{array}$ & -2.913549 & 0.0000 & Stasioner \\
\hline \multirow{3}{*}{$\begin{array}{l}\text { Pembiayaa } \\
\mathrm{n}\end{array}$} & Level & $\begin{array}{l}- \\
0.23012 \\
4\end{array}$ & -2.911730 & 0.9282 & Non Stasioner \\
\hline & $\begin{array}{l}\mathbf{1}^{\text {st }} \\
\text { Difference }\end{array}$ & $\begin{array}{l}- \\
4.41682 \\
2\end{array}$ & -2.912631 & 0.0007 & Stasioner \\
\hline & $\begin{array}{l}2^{n d} \\
\text { Difference }\end{array}$ & $\begin{array}{l}- \\
8.25460 \\
5 \\
-\end{array}$ & -2.913549 & 0.0000 & Stasioner \\
\hline \multirow{3}{*}{$\begin{array}{l}\text { Investasi } \\
\text { PMA dan } \\
\text { PMDN }\end{array}$} & Level & $\begin{array}{l}1.69364 \\
0\end{array}$ & -2.913549 & 0.4290 & Non Stasioner \\
\hline & $\begin{array}{l}\mathbf{1}^{\text {st }} \\
\text { Difference }\end{array}$ & $\begin{array}{l}- \\
1.00084 \\
9\end{array}$ & -2.913549 & 0.7473 & Non Stasioner \\
\hline & $\begin{array}{l}2^{n d} \\
\text { Difference }\end{array}$ & $\begin{array}{l}- \\
12.2150 \\
7 \\
-\end{array}$ & -2.594521 & 0.0000 & Stasioner \\
\hline \multirow{3}{*}{ GDP } & Level & $\begin{array}{l}12.6378 \\
3\end{array}$ & -2.922449 & 0.0000 & Stasioner \\
\hline & $\begin{array}{l}\mathbf{1}^{\text {st }} \\
\text { Difference }\end{array}$ & $\begin{array}{l}- \\
8.21690 \\
6\end{array}$ & -2.923780 & 0.0000 & Stasioner \\
\hline & $\begin{array}{l}2^{n d} \\
\text { Difference }\end{array}$ & $\begin{array}{l}- \\
3.53802 \\
9\end{array}$ & -2.925169 & 0.0111 & Stasioner \\
\hline
\end{tabular}

\subsection{Uji Lag Optimum}

Tabel 2. Hasil Uji Panjang Lag

\begin{tabular}{lllllll}
\hline Lag & LogL & LR & FPE & AIC & SC & HQ \\
\hline 0 & - & NA & $9.28 \mathrm{e}+38$ & 101.0778 & 101.2265 & 101.1350 \\
& - & & & & & \\
1 & 2674.561 & $57.67387^{*}$ & $5.12 \mathrm{e}+38^{*}$ & $100.4800^{*}$ & $101.2235^{*}$ & $100.7659^{*}$
\end{tabular}




\begin{tabular}{lllllll}
\hline Lag & LogL & LR & FPE & AIC & SC & HQ \\
\hline 2 & - & 18.65253 & $6.19 \mathrm{e}+38$ & 100.6599 & 101.9982 & 101.1745 \\
& 2631.486 & & & & & \\
3 & - & 10.42104 & $8.97 \mathrm{e}+38$ & 101.0031 & 102.9362 & 101.7465 \\
& 2624.582 & & & & & \\
4 & - & 14.90543 & $1.14 \mathrm{e}+39$ & 101.1928 & 103.7208 & 102.1650 \\
\hline
\end{tabular}

\subsection{Uji Stabilitas}

Tabel 3. hasil Uji Stabilitas

\begin{tabular}{cc}
\hline Root & Modulus \\
\hline-0.658900 & 0.658900 \\
-0.475315 & 0.475315 \\
-0.450236 & 0.450236 \\
-0.334965 & 0.334965 \\
\hline
\end{tabular}

\subsection{Uji Kointegrasi}

Tabel 4. Hasil Uji Kointegrasi

Unrestricted Cointegration Rank Test (Trace)

\begin{tabular}{lllll}
\hline $\begin{array}{c}\text { Hypothesized } \\
\text { No. of CE(s) }\end{array}$ & Eigenvalue & $\begin{array}{c}\text { Trace } \\
\text { Statistic }\end{array}$ & $\begin{array}{c}\text { 0.05 } \\
\text { Critical Value }\end{array}$ & Prob.** \\
\hline None & & 69.28780 & 40.17493 & 0.0000 \\
At most 1 & 0.418650 & 37.82849 & 24.27596 & 0.0006 \\
At most 2 & 0.367072 & 11.29937 & 12.32090 & 0.0737 \\
At most 3 & 0.157069 & 1.388920 & 4.129906 & 0.2792 \\
\hline
\end{tabular}

Unrestricted Cointegration Rank Test (Maximum Eigenvalue)

\begin{tabular}{|c|c|c|c|c|}
\hline $\begin{array}{l}\text { Hypothesized } \\
\text { No. of CE(s) }\end{array}$ & Eigenvalue & $\begin{array}{l}\text { Max } \\
\text { Eigenvalue } \\
\text { Statistic }\end{array}$ & $\begin{array}{l}0.05 \\
\text { Critical Value }\end{array}$ & Prob.** \\
\hline None ${ }^{*}$ & 0.418650 & 31.45931 & 24.15921 & 0.0043 \\
\hline At most $1 *$ & 0.367072 & 26.52913 & 17.79730 & 0.0019 \\
\hline At most 2 & 0.157069 & 9.910446 & 11.22480 & 0.0844 \\
\hline At most 3 & 0.023662 & 1.388920 & 4.129906 & 0.2792 \\
\hline $\begin{array}{l}\text { Hypothesized } \\
\text { No. of CE(s) }\end{array}$ & Eigenvalue & $\begin{array}{c}\text { Max } \\
\text { Eigenvalue } \\
\text { Statistic }\end{array}$ & $\begin{array}{c}0.05 \\
\text { Critical Value }\end{array}$ & Prob.** \\
\hline None ${ }^{*}$ & 0.418650 & 31.45931 & 24.15921 & 0.0043 \\
\hline At most $1^{*}$ & 0.367072 & 26.52913 & 17.79730 & 0.0019 \\
\hline At most 2 & 0.157069 & 9.910446 & 11.22480 & 0.0844 \\
\hline At most 3 & 0.023662 & 1.388920 & 4.129906 & 0.2792 \\
\hline
\end{tabular}




\subsection{Uji Kausalitas Grenger (Granger Causality Test)}

Tabel 5. Hasil Uji Kausalitas Granger

\begin{tabular}{|c|c|c|c|}
\hline Null Hypothesis: & Obs & F-Statistic & Prob. \\
\hline X2 does not Granger & & 52.6891 & 1.E-09 \\
\hline Cause X1 & 59 & & \\
\hline $\begin{array}{l}\text { X1 does not Granger } \\
\text { Cause X2 }\end{array}$ & & 1.75238 & 0.1910 \\
\hline X3 does not Granger & 5 & 17.4213 & 0.0001 \\
\hline $\begin{array}{l}\text { X1 does not Granger } \\
\text { Cause X3 }\end{array}$ & & 18.7779 & 6.E-05 \\
\hline $\begin{array}{l}\text { Y does not Granger } \\
\text { Cause X1 }\end{array}$ & 59 & 47.8701 & 5.E-09 \\
\hline $\begin{array}{l}\text { X1 does not Granger } \\
\text { Cause Y }\end{array}$ & & 0.00157 & 0.9685 \\
\hline $\begin{array}{l}\text { X3 does not Granger } \\
\text { Cause X2 }\end{array}$ & 59 & 11.6373 & 0.0012 \\
\hline $\begin{array}{l}\text { X2 does not Granger } \\
\text { Cause X3 }\end{array}$ & & 50.4672 & 2.E-09 \\
\hline $\begin{array}{l}\text { Y does not Granger } \\
\text { Cause X2 }\end{array}$ & 59 & 18.5743 & 7.E-05 \\
\hline $\begin{array}{l}\mathrm{X} 2 \text { does not Granger } \\
\text { Cause } \mathrm{Y}\end{array}$ & & 7.86132 & 0.0069 \\
\hline $\begin{array}{l}\text { Y does not Granger } \\
\text { Cause X3 }\end{array}$ & 59 & 47.5262 & 5.E-09 \\
\hline $\begin{array}{l}\text { X3 does not Granger } \\
\text { Cause Y }\end{array}$ & & 28.4233 & 2.E-06 \\
\hline
\end{tabular}

\subsection{Uji Vector Error Correction Model (VECM)}

Tabel 6. Uji VECM Jangka Pendek

\begin{tabular}{lll}
\hline \multicolumn{1}{c}{ Variabel } & \multicolumn{1}{c}{ Koefisien } & \multicolumn{1}{c}{ t-statistik } \\
\hline Cointegrasi 1 & 0.002668 & 0.35331 \\
$\mathrm{D}(\mathrm{X} 1(-1), 2)$ & -0.001016 & -0.06714 \\
$\mathrm{D}(\mathrm{X} 2(-1), 2)$ & 0.007137 & 0.22292 \\
$\mathrm{D}(\mathrm{X} 3(-1), 2)$ & 0.008899 & 0.12471 \\
\hline
\end{tabular}

$T$ tabel $=2,004879288$

Tabel 7. Uji VECM Jangka Penjang

\begin{tabular}{lll}
\hline Variabel & Koefisien & t-statistik \\
\hline $\mathrm{X} 1(-1)$ & 0.000000 & 1.000000 \\
$\mathrm{X} 2(-1)$ & 8.224069 & 4.06697 \\
$\mathrm{X} 3(-1)$ & -12.26582 & -4.38706 \\
\hline
\end{tabular}




\subsection{Variance Decomposition (VD)}

Tabel 8. Hasil Uji Variance Decomposition

\begin{tabular}{cccccc}
\multicolumn{5}{c}{ Variance Decomposition of D(Y) } \\
\hline Period & S.E. & D(Y) & D(X1) & D(X2) & D(X3) \\
\hline 1 & 18721.50 & 100.0000 & 0.000000 & 0.000000 & 0.000000 \\
2 & 21267.27 & 99.47488 & 0.445188 & 0.061671 & 0.018263 \\
\hline
\end{tabular}

\subsection{Impulse Response Function (IRF)}

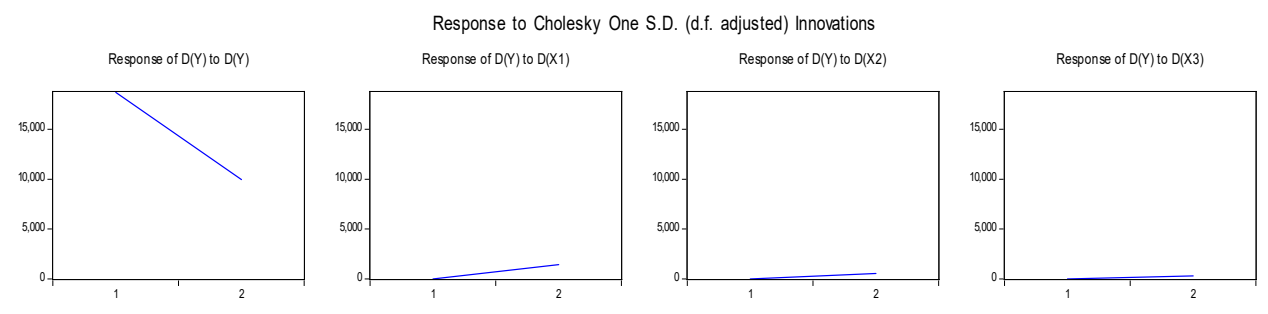

Gambar 1. Hasil Uji IRF

Pembahasan Dari Hasil Analisis Regresi Linier BErganda Dan Statistik Deskriptif Diatas adalah Sebagai Berikut: (a). Kredit Perbankan Konvensional (X1) tidak terdapat pengaruh yang signifikan terhadap pertumbuhan ekonomi (Y) baik dalam jangka pendek maupun jangka panjang. (b) Berdasarkan hasil estimasi VECM variabel Pembiayaan Perbankan Syariah (X2) berpengaruh positif signifikan terhadap PDB dijangka Panjang. Namun, Pembiayaan Perbankan Syariah tidak memiliki pengaruh signifikan di jangka pendek. (c) Berdasarkan hasil estimasi VECM variabel Investasi PMA dan PMDN tidak terdapat pengaruh signiflansi terhadap pertumbuhan ekonomi di jangka pendek. Namun varibael investasi PMA dan PMDN memiliki pengaruh negative signifikan di jangka Panjang.

Kondisi GDP, Kredit Perbankan Konvensional, Pembiayaan Perbankan Syariah Dan Investasi PMA Dan PMDN Pada Kondisi Normal dan Kondisi COVID-19: (a) Kredit Perbankan Konvensional mengalami penurunan di tahun 2020, penurunan dilihat dari nilai rata - rata yang lebih rendah daripada tahun 2019. Hasil penurunan didapat dari nilai signifikansi dalam uji beda samples paired t-test yang menunjukan menunjukan hasil dimana nilai sig. (2-tailed) $<0,05$ yang menunjukan bahwasanya terdapat perbedaan yang nyata antara kredit bank konvensional disaat sebelum datangnya pandemi covid-19 dan pada saat terjadi pandemi covid-19. (b) Pembiayaan Perbankan Syariah mengalami kenaikan di tahun 2020, kenaikan dilihat dari nilai rata - rata yang lebih tinggi daripada tahun 2019. Hasil kenaikan tersebut didapat dari nilai signifikansi dalam uji beda samples paired t-test yang menunjukan menunjukan hasil dimana nilai sig. (2-tailed) $<0,05$ yang menunjukan bahwasanya terdapat perbedaan yang nyata antara pembiayaan Perbankan Syariah disaat sebelum datangnya pandemi covid-19 dan pada saat terjadi pandemi covid-19. Dan perbedaan terletak dimana nilai di tahun 2020 atau ditahun saat adanya pandemic justru naik signifikan. (c) Investasi PMA dan PMDN mengalami penurunan di tahun 2020, penurunan dilihat dari nilai rata - rata yang lebih rendah daripada tahun 2019. Hasil penurunan didapat dari nilai signifikansi dalam uji beda samples paired t-test yang menunjukan menunjukan hasil dimana nilai sig. (2-tailed) < 0,05 yang menunjukan bahwasanya terdapat perbedaan yang nyata antara Investasi PMA dan PMDN disaat sebelum datangnya pandemi covid-19 dan pada saat terjadi pandemi covid-19. 
(d) PDB mengalami penurunan di tahun 2020, penurunan dilihat dari nilai rata - rata yang lebih rendah daripada tahun 2019. Hasil penurunan didapat dari nilai signifikansi dalam uji beda samples paired t-test yang menunjukan menunjukan hasil dimana nilai sig. (2-tailed) $<0,05$ yang menunjukan bahwasanya terdapat perbedaan yang nyata antara PDB disaat sebelum datangnya pandemi covid-19 dan pada saat terjadi pandemi covid-19.

\section{Simpulan}

\subsection{Kesimpulan}

Kredit Perbankan Konvensional (X1) tidak terdapat pengaruh yang signifikan terhadap pertumbuhan ekonomi (Y) baik dalam jangka pendek maupun jangka panjang.

Berdasarkan hasil estimasi VECM variabel Pembiayaan Perbankan Syariah (X2) berpengaruh positif signifikan terhadap PDB dijangka Panjang. Namun, Pembiayaan Perbankan Syariah tidak memiliki pengaruh signifikan di jangka pendek. Jadi apabila pembiayaan perbankan syariah mengalami kenaikan di jangka panjang maka akan menyebabkan pertumbuhan ekonomi di Indonesia meningkat dalam jangka panjang. Begitupun sebaliknya, ketika pembiayaan perbankan syariah menurun maka akan menurunkan pertumbuhan ekonomi. Hal ini disebabkan oleh beberapa faktor yaitu : (a) Untuk memenuhi kebutuhan jasa perbankan bagi masyarakat yang menganggap bunga bank Konvensional adalah riba (usury/interest). (b) Mengakomodasi penampungan aliran modal dari pemilik dana dalam negeri dan dari Lembaga - Lembaga keuangan yang berasal dari internasional yang mensyaratkan penerapan landasan Syariah. (c) Produk dan jasa Perbankan Syariah lebih variative, karena dapat merupakan kombinasi dari produk commercial bank (kegiatan bank umum), finance company (ijarah), investment bank (mudharabah dan musharakah). (d) Melengkapi pelayanan jasa dibidang perbankan selain jasa perbankan konvensional. (Wangsawidjaja 2012: 17). (e) Berdasarkan hasil estimasi VECM variabel Investasi PMA dan PMDN tidak terdapat pengaruh signiflansi terhadap pertumbuhan ekonomi di jangka pendek. Namun varibael investasi PMA dan PMDN memiliki pengaruh negative signifikan di jangka Panjang. Artinya jika Investasi Penanaman Modal Asing (PMA) dan Penanaman Modal Dalam Negeri (PMDN) meningkat maka pertumbuhan ekonomi di Indonesia akan menurun.

Selain itu, penelitian ini juga ingin mengetahui kondisi pertumbuhan ekonomi (GDP), kredit perbankan konvensional, pembiayaan perbankan syariah investasi PMA dan PMDN, sebelum masa pandemi COVID-19 (2019) dan pada masa pandemi COVID-19 (2020) melalui uji beda samples paired t test yaitu sebagai berikut: (a) Kredit Perbankan Konvensional mengalami penurunan di tahun 2020, (b) Pembiayaan Perbankan Syariah mengalami penurunan di tahun 2019 dan justru meningkat ditahun 2020. (c) Investasi PMA dan PMDN mengalami penurunan di tahun 2020, (d) Pertumbuhan ekonomi melalui GDP mengalami penurunan di tahun 2020/

\subsection{Saran}

Berdasarkan hasil penelitian ini maka saran-saran yang dapat diberikan adalah sebagai berikut: (a) Bagi peneliti selanjutnya diharapkan menjadi landasan penelitian berikutnya dan variabel independen diperbanyak menggunakan variabel yang lain untuk melihat bagaimana pengaruh perbankan konvensional, perbankan syariah dan investasi PMA dan 
PMDN terhadap pertumbuhan ekonomi di Indonesia, serta disarankan untuk menggunakan metode analisis yang berbeda, sehingga mendapat hasil yang berbeda dan mengembangkan hasil dari penelitian ini. (b) Bagi pihak perbankan diharapkan hasil penelitian ini dapat dijadikan sebagai bahan rujukan dan evaluasi dalam mengelola bank menjadi lebih baik lagi. (c) Bagi Badan Koordinasi Penanaman Modal (BKPM) diharapkan hasil penelitian ini dapat dijadikan sebagai bahan pertimbangan sebagai salah satu solusi yang baik saat kondisi pandemi seperti saat ini. (d) Bagi pihak masyarakat diharapkan hasil penelitian ini dapat dijadikan sebagai bahan pertimbangan agar tetap menginvestasikan atau menabungkan sebagian dari pendapatannya kepada pihak perbankan.

\section{Daftar Rujukan}

Aulia, A. (2013). Analisis Pengaruh Ekspor Neto, Inflasi, Pma Dan Pmdn Terhadap Pertumbuhan Ekonomi Di Indonesia Periode 2000-2012.

Bkpm (2015) Realisasi Penanaman Modal PMA Dan PMDN Triwulan IV tahun 2015.

Bkpm (2016) Realisasi Penanaman Modal PMA Dan PMDN Triwulan IV tahun 2016.

Bkpm (2017) Realisasi Penanaman Modal PMA Dan PMDN Triwulan IV tahun 2017.

Bkpm (2018) Realisasi Penanaman Modal PMA Dan PMDN Triwulan IV tahun 2018.

Bkpm (2019) Realisasi Penanaman Modal PMA Dan PMDN Triwulan IV tahun 2019.

Boukhatem, J., \& Moussa, F. B. (2018). The effect of Islamic banks on GDP growth: Some evidence from selected MENA countries. Borsa Istanbul Review, 18(3), 231-247.

Bps (2015) Laporan PDB tahunan Indonesia tahun 2015-2010.

Furqani, H., \& Mulyany, R. (2009). Islamic banking and economic growth: Empirical evidence from Malaysia. Journal of Economic Cooperation \& Development, 30(2).

Haryati, Sri. (2009). Pertumbuhan Kredit Perbankan di Indonesia: Intermediasi dan Pengaruh Variabel Makro Ekonomi. Jurnal Keuangan Dan Perbankan 13 (2): 299-310.

Helmi, M. H., et al. (2018). Islamic Banking, Credit, and Economic Growth: Some Empirical Evidence. Int J Fin Econ 23:456-477. Doi: 10.1002/Ijfe.1632.

Jufrida, Firdaus., Syechalad, M. N., dan Nasir, Muhammad. (2016). Analisis Pengaruh Investasi Asing Langsung (FDI) dan Investasi Dalam Negeri Terhadap Pertumbuhan Ekonomi Indonesia. Jurnal Perspektif Ekonomi Darussalam 2 (1).

Kambono, Herman. (2020). Pengaruh Investasi Asing dan Investasi Dalam Negeri Terhadap Pertumbuhan Ekonomi Indonesia. Jurnal Akuntansi 12 (1):137-145.

Ojk (2015) Statistik Perbankan Indonesia bulan Desember Tahun 2015.

Ojk (2016) Statistik Perbankan Indonesia bulan Desember Tahun 2016.

Ojk (2017) Statistik Perbankan Indonesia bulan Desember Tahun 2017.

Ojk (2018) Statistik Perbankan Indonesia bulan Desember Tahun 2018.

Ojk (2019) Statistik Perbankan Indonesia bulan Desember Tahun 2019.

Ojk (2015) Statistik Perbankan Syariah bulan Desember Tahun 2015.

Ojk (2016) Statistik Perbankan Syariah bulan Desember Tahun 2016.

Ojk (2017) Statistik Perbankan Syariah bulan Desember Tahun 2017.

Ojk (2018) Statistik Perbankan Syariah bulan Desember Tahun 2018.

Ojk (2019) Statistik Perbankan Syariah bulan Desember Tahun 2019.

Rafsanjani, H., \& Sukmana, R. (2014). Pengaruh perbankan atas pertumbuhan ekonomi: studi kasus bank konvensional dan bank syariah di Indonesia. Jurnal Aplikasi Manajemen, 12(3), 492-502.

Setiawan, Iwan. (2020). Analisis Peran Perbankan Terhadap Pertumbuhan Ekonomi di Indonesia: Bank Syariah Versus Bank Konvensional. Jurnal Akuntansi, Ekonomi Dan Manajemen Bisnis 8 (1): 52-60. 
Jurnal Ekonomi, Bisnis dan Pendidikan, 1(9), 2021, 844-853

Sodik, Jamzani dan Nuryadin, Didi. (2005). Investasi dan Pertumbuhan Ekonomi Regional (Studi Kasus pada 26 Propinsi di Indonesia, Pra dan Pasca Otonomi). Jurnal Ekonomi Pembangunan 10 (2): 157-170.

Sulistiawati, Rini. (2012). Pengaruh Investasi Terhadap Pertumbuhan Ekonomi dan Penyerapan Tenaga Kerja Serta Kesejahteraan Masyarakat di Provinsi di Indonesia. Jurnal Ekonomi Bisnis Dan Kewirausahaan 3 (1): 29-50. 